\title{
ANALYSIS OF THE FACTORS THAT INFLUENCE THE GROWTH OF SHARIA INSURANCE INDUSTRY ASSETS IN INDONESIA (2016-2020 PERIOD)
}

\author{
Hilman Suryadi ${ }^{1}$, Jaenal Effendi ${ }^{2}$ \\ Bogor Agricultural University (IPB University) \\ hilmansuryadimr@gmail.com¹, jaenfendi@gmail.com²
}

DOI:

\begin{abstract}
This study aims to look at the description and influence of contributions, claims, investment returns, inflation, JCI, and bank indonesia sharia certificate yields on the growth of Sharia insurance industry assets in Indonesia for the 2016-2020 period, both simultaneously and partially. The data used are secondary data for the monthly period in 2016-2020.

This study uses multiple linear regression analysis with the help of Eviews 10 software to see the effect of the independent variable on the dependent variable.

Based on the research results, simultaneously all variables have a significant effect on asset growth. Partially, the claims variable and the JCI have a significant negative effect on asset growth, while the contribution and investment return variables have a significant positive effect on asset growth, then the inflation variable and BANK INDONESLA SHARIA CERTIFICATE yield have no significant effect on the growth of Islamic insurance industry assets in Indonesia.
\end{abstract}

Keywords: Asset Growth, Sharia Insurance

\section{Introduction}

One of the efforts to minimize the impact of losses from risks that may occur in the future is to use insurance. Mashnu'ah (2010) states that insurance is a financial means in the order of household life, either in facing basic risks such as the risk of death, or in protecting property from damage due to accidents or disasters in the future.

Based on data from the World Population Review, number of muslim population in Indonesia in 2020 reached 229 million people or 87.2 percent of the total population of Indonesia and it made Indonesia the country with the largest Muslim population in the world. In this case, Indonesia has tremendous potential for the growth and development of sharia-based economic activities, including sharia insurance (Sawitri 2011). 
Sharia insurance industry development in Indonesia based on Statistical Data on the Sharia Non-Bank Financial Industry (IKNB) of the Financial Services Authority, as of December 2020 there were 60 insurance and reinsurance corporates based on sharia principles. This number increased by 22.45 percent compared to the number of corporates in 2013, which were 49 corporates. The development of the sharia Insurance industry in Indonesia may also be seen from the number of assets. In 2019, the total assets of the sharia insurance industry were only 3.43 percent of the total assets of conventional insurance in Indonesia (OJK Sharia IKNB 2020). Such number is clearly not proportional to the number of muslim population as the majority population in Indonesia, coupled with the spin-off mandate from the government as stated in Law no. 40 of 2014 concerning Insurance. Certainly, this requires efforts to grow the assets of the Islamic insurance industry to face the spin-off rules in order to compete in the insurance industry in Indonesia.

Asset growth is the annual rate of change of total assets. An increase in the number of assets followed by an increase in operating results will increase the confidence of outsiders in the corporate (Ainul, et al. 2017). Sharia insurance industry assets amounted to IDR 45,453 billion in 2019, an increase from the previous year which amounted to IDR 41,959 billion. Meanwhile, the growth rate of sharia insurance assets is still volatile in Indonesia. So that, it indicates that there is a problem in the sharia insurance industry in terms of the consistency of asset growth. Factors that may affect the growth of Islamic insurance assets are divided into internal and external factors (Ulandari, 2017). Internal conditions may be observed, the corporate refers to the performance of the corporate itself, including the variables to be studied, namely contributions, investment returns, and claims. Corporates may refer to the corporate's performance itself to observe internal conditions, such as variables to be studied, namely contributions, investment returns, and claims. For external factors, it may be in the form of macroeconomic conditions of a country that may affect the sharia insurance industry. In this study, the selected external factors in influencing the growth of Islamic insurance industry assets are inflation, JCI and Bank Indonesia Sharia Certificate Yields. Previous studies on the growth of sharia insurance assets have been widely carried out. However, the studies that have been done has only examined the internal factors of sharia insurance corporate. Most of studies on external factors related to sharia insurance assets has been widely studied by using profitability is proxied by Return on Assets (ROA) as the dependent variable.

Assets for insurance corporates are very important both to fulfil long-term and short-term obligations. The long-term obligations of insurance corporates such as the expiration of insurance contracts and claims of insurance participants. The short-term obligations include reinsurance debt, tax payable, and operating costs (Sastrodiharjo and Sutama 2015). This study was conducted to analyze that high asset growth indicates that the corporate may optimize its assets well. So that it may maintain public trust in sharia 
insurance corporates, for that the sharia insurance industry needs to carry out supervision and analysis of asset growth.

\section{Review of Related Literature}

\section{Sharia Insurance Industry}

According to Kuncoro (2007) industry in a narrow sense is a collection of corporates that produce similar products where there are similarities in the raw materials used, processes, final products and end consumers. In a broader definition, industry is a collection of corporates that produce goods and services with a positive and high cross elasticity. Industry is a group of corporates that carry out similar activities or produce homogeneous goods (Julianto, Suparno 2016).

Based on the industry definition, sharia insurance is divided into several types of businesses that carry out insurance activities in accordance with sharia principles. In this case, the sharia insurance corporate, although with different types of business, has one thing in common, it is carrying out insurance activities, which can be called the sharia insurance industry. Hasan (2014) explained that there are three types of takaful businesses or sharia insurance whose form is in accordance with and equated with the three types of insurance businesses in Law no. 2 of 1992, Family Takaful (Life Insurance), General Takaful (loss insurance), Retakaful (reinsurance). Conventional insurance companies can also have sharia business units that are part of the sharia insurance industry.

First, Asset growth is the annual rate of change of total assets. An increase in assets followed by an increase in operating results will further increase the trust of outsiders in the corporate (Budiasa et al. 2016). Asset growth is calculated as a percentage of the corporate's assets in a certain year against the previous year (Fadhli 2010). The variable scale used is the ratio variable which is a comparison variable. The growth equation is formulated as this year's total assets minus the previous year's total assets divided by last year's total assets. Asset growth is expected for the development of the corporate, both internal and external to the corporate. Corporates that have high growth may give a sign for the corporate's development and provide a positive view for investors (Triyani et al. 2018). The larger the assets, it is expected that the resulting operational results will also be greater.

Second, Contribution. Contribution is the term of premium in sharia insurance, which is a sum of money that shall be paid regularly by each participant to the corporate. Some sharia insurance experts call such term of premium with contribution (contribution) or in the language of figh (Islamic jurisprudence) called al-Musahamah. Sula (2004) states that $A l$ Musabamah (contribution) in a takaful agreement (sharia insurance) is a financial consideration (al-'iwad) on the part of the participant which is an obligation that arises from the agreement between the participant and the manager. Consideration is needed not only from one party but both parties. Then, the manager is also simultaneously bound by the agreement, both in terms of compensation and profits. 
Sharia insurance corporates are trusted by participants to manage premiums, develop them in a lawful way and provide compensation to those who experience disasters in accordance with the agreement. The larger the size of the insurance corporate, it will be easier to obtain funds and operate it so that it can be predicted that the increase in asset growth will be faster than corporates with smaller scales (Sastrodiharjo and Sutama 2015). The greater the contribution paid by the insured, the greater the funds received by the insurance corporate in the form of contribution income (Nasution and Sistiyani 2019). The funds received will then be invested by the insurance corporate in the form of assets. Therefore, the contribution has a positive effect on asset growth. Sastrodiharjo and Sutama (2015) in their study succeeded in proving that premiums or contributions are important factors that affect the growth of insurance corporate assets.

Third, Claim. Claims are the rights of insurance participants that must be provided by the insurance corporate according to the agreement in the contract (Sholihin and Ilham 2010). Payment of claims on sharia insurance is taken from the tabarru' funds of all participants. In payment of claims, participants in sharia life insurance are classified into three categories, they are participants who are affected by disaster, participants whose contract period has expired, and participants who resign. Whereas in general sharia insurance in resolving claims in the form of damage or loss, sharia insurance companies refer to contracts and agreements written in the policy with two options; first, replacement with cash and second, repairing or rebuilding damaged objects. In general, the types of losses can be classified into three, total loss, partial loss and third-party loss.

Claim settlement procedures for both sharia and conventional general insurance are almost the same, except in terms of speed and honesty in assessing claims (Sula 2004). If the insurance corporate's claim risk is higher, it is predicted that it will have an impact on its ability to grow the corporate's assets (Sastrodiharjo and Sutama 2015). The higher the level of claims submitted by the insured, the greater the funds issued by the insurance corporate. This indicates that the costs incurred by insurance companies are getting bigger. The amount of costs or expenses incurred by the corporate will reduce the corporate's ability to invest in assets so that it has an impact on decreasing asset growth (Nasution and Sistiyani 2019). Therefore, claims have a negative effect on asset growth. Study conducted by Ikhsan et al. (2015) proves that claims have a significant negative effect on the growth of insurance corporate assets.

Fourth, Investment Returns. Investment returns are the result of the operation of the insurance corporate so that a large amount of money is collected to be distributed to insurance participants (Amrin 2006). Investment funds are taken from participant contributions which have previously been divided into three fund accounts: tijarah, tabarru', and $u j r o h$. The three funds are invested in investment instruments based on sharia and have not been profit-shared. The investment returns from the tabarru' fund become the collective rights of the participants, while the investment returns from the tijarab funds will 
be shared based on the mudharabah contract (Sholihin and Ilham 2010), while the results of the investment of ujroh funds are wholly owned by the corporate.

According to Nasution and Sistiyani (2019), the higher a corporate's ability to manage its investments, the higher the growth of the corporate's assets. Good investment returns will encourage companies to continue to increase their total assets. In addition, increased investment may provide a positive signal for corporate investors. Study conducted by Sastrodiharjo and Sutama (2015) succeeded in proving that the value of investment returns has a positive effect on the growth of life insurance corporate assets. Some insurance companies prefer to make investments that have a higher rate of return in order to increase their asset growth (Nasution and Sistianingsih 2019).

Fifth, Inflation. Suseno and Astiyah (2009) explain that inflation is defined as an increase in the money supply or an increase in liquidity in an economy. Briefly, inflation may be interpreted as a tendency to increase the prices of goods and services in general and continuously. The existence of inflation, then the purchasing power of a currency becomes lower or decreases. With the decline in the purchasing power of the currency, the ability of people with fixed income to buy goods and services for their daily needs will be lower. The inflation rate has a considerable influence on macroeconomic conditions. In the event of inflation occurs, there will be uncertainty in the macroeconomic conditions of a country which results in people not having excess funds to be stored in savings or invested (Rahim and Hendrisman 2013). According to Cahyani (2018), inflation is not known in Islamic economics, since in Islamic economics the currency used is dinnar and dirham which have a stable value. The impact of inflation on the insurance industry according to Karl (2012) is that inflation may lead to an increase in claim costs, resulting in a decrease in the profitability of general insurance companies.

Sicth, Composite Stock Price Index (IHSG). The price index is a number used to compare an event with other events. Stocks are capital market instruments that are most in demand by investors. The composite stock price index is a number that shows the general movement of stocks listed on the stock exchange to measure changes in stock prices (Pasaribu and Kowanda 2014).

IHSG or JCI (Jakarta Composite Index) was first introduced on April 1, 1993 as an indicator of stock price movements listed on the stock exchange, both common stock and preferred stock (IDX 2018). JCI uses listed companies as parent components in calculating index numbers. The Indonesia Stock Exchange (IDX) has special authority to replace one or more listed companies as an illustration of market conditions from the calculation side. The Composite Stock Price Index (JCI) is a forum for companies that open their share ownership to the public through an Initial Public Offering (IPO) mechanism. So that the JCI is a documentation of stock price movements either when they have decreased or increased. According to study conducted by Khairina (2020) found study results stating that the JCI has a significant and positive effect on the investment returns of sharia life insurance 
in Indonesia. Good investment returns will encourage companies to increase their total assets (Nasution and Sistiyani 2019).

Secenth. Bank Indonesia Sharia Certificate Yield. Bank Indonesia Sharia Certificates are securities based on sharia principles that have short terms in rupiah currency issued by Bank Indonesia (Bank Indonesia 2008). The mechanism used in issuing Bank Indonesia Sharia Certificate through auction is that it may only be followed by Sharia Commercial Banks (SCB), Sharia Business Units (SBU) and brokers acting for and on behalf of SCB and SBU. Parties who may participate in the auction process shall meet the requirements for the Financing to Deposit Ratio set by Bank Indonesia. The reward generated from the Bank Indonesia Sharia Certificate is in the form of a bonus level that is in accordance with the number of Bank Indonesia Sharia Certificate ownership. The reward for the Bank Indonesia Sharia Certificate that has been determined by Bank Indonesia will be given at the maturity date of the Bank Indonesia Sharia Certificate. The higher Bank Indonesia Sharia Certificate yield rate will attract consumers' attention to invest so as to reduce consumer demand for sharia insurance products. The high yield of Bank Indonesia Sharia Certificate tends to cause the function of insurance products as an investment instrument to become less attractive in the eyes of consumers (Outreville 2011).

\section{Study Method}

This study is a regression study with a quantitative approach. The type of data used is secondary data in the form of a monthly time series for the period January 2016 to December 2020. The data sources come from the Non-Bank Financial Industry with Sharia Statistics of Financial Services Authority, Indonesian Economic and Financial Statistics of Bank Indonesia, and Yahoo Finance.

The analytical method used is descriptive analysis and quantitative analysis. Descriptive analysis was used to determine the development of the variables used in the study. The quantitative analysis used is multiple linear regression analysis using Microsoft Excel 2013 software to group data and then processed using EViews 10 software.

\section{Results and Discussion}

\section{Overview of Sharia Insurance Industry Asset Growth in Indonesia}

Asset growth is the annual rate of change of total assets. An increase in assets followed by an increase in operating results will further increase the trust of outsiders in the corporate (Budiasa et al. 2016). Asset growth is calculated as a percentage of the corporate's assets in a certain year against the previous year (Fadhli 2010). The growth of sharia insurance industry assets in Indonesia for the period 2016 to 2020 may be seen in the sharia insurance financial data released by the Non-Bank Financial Industry with Sharia Statistics of Financial Services Authority, as shown in Figure 1 below. 
Figure 1

Growth of sharia insurance industry assets in 2016-2020.

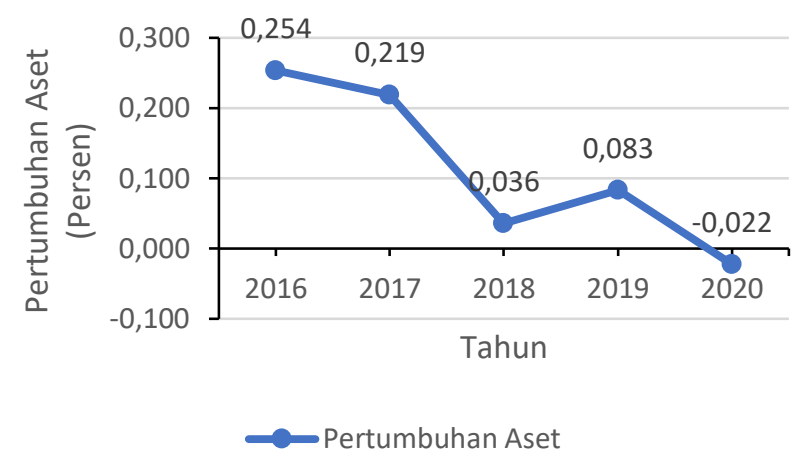

Source: Non-Bank Financial Industry with Sharia of Financial Services Authority (processed data)

Based on Figure 1, the growth of sharia insurance industry assets in 2016 was at 0.254 percent, then the following year there was a decrease in asset growth at 0.219 percent in 2017. In 2018, asset growth decreased significantly by 0.036 percent, the total assets of the sharia insurance industry in 2018 amounted to IDR 41,959 billion, compared to the previous year in 2017 of IDR 40,520 billion or an increase of IDR 1,439 billion from 2017. That was in contrast to the increase in total assets in 2017, there was an increase of IDR 7,276 billion from 2016. The significant decline in the asset growth of the sharia insurance industry in 2018 from 2017 was explained by the Director of the Non-Bank Financial Industry with Sharia of Financial Services Authority, such matter was occurred because in 2017 the projected growth of sharia insurance assets is 17 percent and a contribution of 20 percent, while in 2018 the figure is lower, the projected growth of sharia insurance assets is 15 percent and a contribution of 17-18 percent (Kulsum 2018). Table 1 shows the total investment returns, contributions, and claims of the sharia insurance industry in Indonesia in 2015-2020.

\section{Table 1}

Total investment returns, contributions, and claims of the sharia insurance industry in Indonesia in 2015-2020 (Billion Rupiah)

\begin{tabular}{|l|c|c|c|c|c|c|}
\hline Indicator & $\mathbf{2 0 1 5}$ & $\mathbf{2 0 1 6}$ & $\mathbf{2 0 1 7}$ & $\mathbf{2 0 1 8}$ & $\mathbf{2 0 1 9}$ & $\mathbf{2 0 2 0}$ \\
\hline $\begin{array}{l}\text { Investment } \\
\text { Return }\end{array}$ & -376.18 & $2,475.25$ & 2,346 & 65,82 & 2.193 & 656 \\
\hline $\begin{array}{l}\text { Gross } \\
\text { Contribution }\end{array}$ & $10,488.75$ & $12,028.34$ & 13,995 & 15368.55 & 16.704 & 17.345 \\
\hline Gross Claim & $3,341.83$ & $4,335.51$ & 4948 & 7582,61 & 10.605 & 12.921 \\
\hline
\end{tabular}

Source: Non-Bank Financial Industry with Sharia Statistic in 2020 (processed data)

Table 1 above shows that in 2018 the number of gross claims increased significantly by IDR 2,634.61 billion but was not followed by a significant increase in gross contribution 
which was only IDR 1,373.55 billion. In addition, the decline in the gross contribution of sharia insurance in 2018 was caused by the impact of an unfavorable investment climate and obstacles in the growth of sharia banking. In 2018, the Composite Stock Price Index (JCI) tended to fluctuate, causing investment returns to the sharia insurance industry as a whole to be minus IDR 65.82 billion, or a decrease of -97.19 percent. This has implications for the growth of sharia insurance industry assets which declined drastically in 2018, in accordance with the Financial Service Authority statement that the growth of the sharia insurance industry declined in 2018.

The growth of Islamic insurance industry assets in 2019 increased again, although not significantly at 0.083 percent, this was due to the recovery in the performance of Islamic insurance industry assets growth as an implication of the growth of Islamic insurance assets in 2018, causing the increase in growth to slow down compared to 2016 and 2017. Then in 2020 there was a significant decline again at -0.022 percent.

The COVID-19 pandemic has suppressed the performance of the Islamic insurance industry until the end of 2020 which can be seen from the asset growth indicators (Republika 2021). The total assets of the sharia insurance industry amounted to IDR 44,440 billion, smaller than in 2019 which amounted to IDR 45,453 billion, a decrease of IDR 1,013 billion or -2.23 percent. This is an implication of a decrease in investment returns of IDR 1,537 billion or a decrease of 70.08 percent YoY in 2020. Investment returns in 2020 amounted to IDR 656 billion, a decrease from 2019 which amounted to IDR 2,193 billion. Meanwhile, the portion of sharia insurance investment is dominated by capital market products with 81.40 percent of the total investment. This means that sharia insurance companies during the pandemic remain optimistic that placements in the capital market will provide better results amid the volatility of the capital market during the pandemic (Sari and Dewi 2021). If detailed, sharia shares provide the largest portion in the investment placement of Indonesian sharia insurance company funds, which reached IDR 13.09 trillion or 35.05 percent of the total investment. Meanwhile, sukuk is still in the last position in investment options, namely IDR 2.29 trillion or 6.13 percent of the total investment. Then 18.15 percent deposits, 17.95 percent Sharia SBN and others (OJK Sharia IKNB 2020 Statistics).

\section{Analysis of Factors Affecting the Growth of Islamic Insurance Industry Assets in Indonesia}

\section{Classical Assumption Test}

The results of the classical assumption test show that the model is normally distributed and free from problems of autocorrelation, heteroscedasticity, and multicollinearity. In the normality test in the study using the Jarque-Bera Test. Based on the results of the normality test, the Jarque-Bera Test value is 0.66 which is greater than the 5 percent significance level, meaning that the residuals are normally distributed, which means that the classical assumptions about normality have been met. 
In the heteroscedasticity test using the Breusch-Pagan-Godfrey test. The result shows the value of Prob. Chi square (3) in Obs*R-Squared is 0.1538 which is greater than the 5 percent significance level, then the four independent variables (independent) do not have heteroscedasticity problems.

The multicollinearity test results show the VIF value of the contribution variable is 6.644758 , the VIF value of the claims variable is 8.506264 , the VIF value of the investment return variable is 1.667325 , the VIF value of the inflation variable is 2.694149 , the JCI variable value is 1.137168 , and the VIF value of the SBIS rate variable. of 1.922504 which indicates that the six independent variables have a VIF value of less than ten, then the variable does not violate the multicollinearity assumption in the research model.

The autocorrelation test used the Durbin - Watson test (DW test). The results of the autocorrelation test for the $\mathrm{Dw}$-statistical value of 1.858700 which is greater than the upper limit (du) of 1.8082 from the Durbin-Watson table and less than 4-du of 2.1918, so it can be concluded that there is no autocorrelation symptom.

\section{Multiple Linear Regression Analysis}

Here are the results of multiple linear regression. First: The value of the contribution factor coefficient (X1) is 1.88703, meaning that if there is an increase in the contribution factor (X1) by 1 percent with the assumption that other variables are constant, it will result in an increase in asset growth $(\mathrm{Y})$ of 1.88703. Second, the value of the claim factor coefficient (X2) is -4.43537, meaning that if there is a 1 percent decrease in the claim factor (X2) assuming other variables are constant, it will result in a decrease in asset growth $(\mathrm{Y})$ of 4.43537 .

The third value of the investment return factor coefficient (X3) is 3.20670, meaning that if there is an increase in the investment return factor (X3) by 1 percent with the assumption that other variables are constant, asset growth will increase by 3.20670. Fourth, the value of the coefficient of inflation (X4) is 2.18329, meaning that if there is an increase in the inflation factor (X4) of 1 percent with the assumption that other variables are constant, it will result in an increase in asset growth $(\mathrm{Y})$ of 2.18329 .

Fifth, the coefficient value of the JCI factor (X5) is -4.21694, meaning that if there is a decrease in the JCI factor (X5) by 1 percent assuming other variables are constant, it will result in a decrease in asset growth $(\mathrm{Y})$ of 4.21694. Sixth, the coefficient of the SBIS rate factor (X6) is -1.80626 , meaning that if there is a 1 percent decrease in the SBIS rate factor (X6) assuming other variables are constant, it will result in a decrease in asset growth (Y) of 1.80626.

Based on the results of the $F$ test in Appendix 5 the prob value. F (statistic) of 0.00 is smaller than the 0.05 significance level, then the contribution factor (X1), claims factor (X2), investment return factor (X3), inflation factor (X4), JCI factor (X5), SBIS rate factor (X6) has a significant effect on asset growth (Y). The R-Square value in this study is 0.789583 , which means that 78.96 percent of the independent variables (independent) affect 
the dependent variable (bound), and the remaining 21.04 percent is influenced by factors outside the variables used.

\section{Factor Analysis of Partial Test Results (T Test):}

Table 2

Summary of $\mathbf{T}$ Test results

\begin{tabular}{|l|l|l|}
\hline Variable & t-Statistic & Prob. \\
\hline C & 4.085727 & 0.0001 \\
\hline X1 & 4.341036 & 0.0001 \\
\hline X2 & -6.113674 & 0.0000 \\
\hline X3 & 5.809443 & 0.0000 \\
\hline X4 & 1.294860 & 0.2010 \\
\hline X5 & -3.021027 & 0.0039 \\
\hline X6 & -1.545235 & 0.1282 \\
\hline
\end{tabular}

Source: Processed data (2021)

The results of the partial test of the contribution factor (X1) obtained a tcount of 4.085727 with a probability value of 0.0001 while $t$-table was 1.67356 . Because tcount $>$ ttable and the probability value is less than 0.1 , it means that the contribution factor has a significant and positive effect on asset growth. The results of this study are in accordance with the research of Lilavira and Zulaikha (2020) which states that the contribution has a significant and positive effect on the growth of Islamic insurance assets.

Partial test results obtained tcount value of -6.113674 with a probability value of 0.0000 while ttable 1.67356. Because tcount $<\mathrm{t}$ table and the probability value is less than 0.1 , it means that the claim factor has a significant and negative effect on asset growth. The results of this study are in accordance with the research of Nasution and Sistiyani (2019), Ainul et al (2017), Sastrodiharjo and Sutama (2015), and Ikhsan et al. (2015) which states that claims have a significant effect on the growth of Islamic insurance assets.

Partial test results obtained tcount value of 5.809443 with a probability value of 0.0000 while ttable 1.67356. Because tcount $>$ ttable and the probability value is less than 0.1 , it means that the investment return has a significant and positive effect on asset growth. The results of this study are in accordance with the research of Nasution and Sistiyani (2019), Ainul et al (2017), Sastrodiharjo and Sutama (2015) which state that investment returns have a significant effect on the growth of Islamic insurance assets.

Partial test results obtained tcount value of 1.294860 with a probability value of 0.2010 while $t$ table is 1.67356 . Because tcount $<$ ttable and the probability value is greater than 0.1 , it means that the inflation factor has no significant effect on asset growth. The results of this study are in line with the research of (Faoziyyah \& Laila, 2020), and Alomari and Azam (2017).

Inflation factor does not have a significant influence on the growth of Islamic insurance industry assets according to Alhasymi, (2012), increasing inflation will increase the risk in investment projects resulting in decreased investment returns. This is in line with 
the theory that investment returns have a significant and positive effect on asset growth. If inflation does not affect the investment returns of Islamic insurance, then inflation will also not affect the growth of Islamic insurance industry assets.

Partial test results obtained tcount value of -3.021027 with a probability value of 0.0039 while ttable 1.67356 . Because tcount $<$ ttable and the probability value is less than 0.1 , it means that the JCI factor has a significant and negative effect on asset growth. The negative relationship between the JCI and the growth of Islamic insurance industry assets means that if the JCI increases, the growth of Islamic insurance industry assets will decrease.

In Khairina's research (2020) it was found that the JCI had a positive and significant effect on the investment returns of sharia life insurance in Indonesia, which means that if the JCI increases, the investment returns will also increase so that the growth of sharia insurance assets can also increase. However, in this study, during the period from 2016 to 2020, the JCI was found to have a significant and negative effect on the growth of Islamic insurance industry assets. The assumption of the researcher, this is due to the increase in the JCI resulting in more funds invested by the Islamic insurance industry being spent. In addition, the investment portion of the sharia insurance industry according to OJK Sharia IKNB data (2020) is the largest in sharia shares which reached IDR 13.09 trillion or 35.05 percent of the total investment. This resulted in the JCI to have a negative and significant effect on the growth of Islamic insurance industry assets.

Partial test results obtained tcount value of -1.545235 with a probability value of 0.1282 while ttable 1.67356 . Because tcount $<\mathrm{t}$ table and the probability value is greater than 0.1 , it means that the SBIS yield factor has no significant effect on asset growth. The negative relationship between SBIS yields and the growth of Islamic insurance industry assets means that if the SBIS yields increase, it will cause the growth of Islamic insurance industry assets to decline. The results of the study on the significance of the factors contradicted Farizka's (2019) research. This can be caused by the thinking of most Indonesians who think that insurance and investment products have the same function, namely to provide security guarantees in the future. This causes people to feel they have to choose one of these financial products, even though insurance and investment products are different in concept and practice.

\section{Conclusion}

The development of the number of Islamic insurance industry assets has increased every year from 2016 to 2019, then in 2020 it decreased due to the COVID-19 pandemic. In contrast to the number of assets of the Islamic insurance industry in Indonesia, which tends to increase every year, the growth of Islamic insurance industry assets has fluctuated growth.

Simultaneously, the results of the study show that there is a significant influence between contribution variables, claims, investment returns, inflation, JCI, and SBIS returns on the growth of Islamic insurance industry assets in Indonesia for the period 2016 to 2020. 
Partially, contribution variables and investment returns show positive and significant influence on the growth of Islamic insurance industry assets in Indonesia for the period 2016 to 2020. While the claims variable and the JCI partially show a negative and significant influence on the growth of Islamic insurance industry assets in Indonesia for the period 2016 to 2020. Inflation and SBIS yield variables partially have no significant effect on the growth of Islamic insurance industry assets in Indonesia for the period 2016 to 2020.

\section{BIBLIOGRAPHY}

Antonio, Muhammad Syafi'i, Islamic banking from theory to practice, Jakarta: Gema Insani Press, 2001.

Libraries in the form of scientific journals:

Widyanto, Eko Adi. “Analysis of the Bank's Financial Soundness and Performance Level Using the CAMEL Method (Case Study at PT. Bank Mega Syariah Indonesia Period 2008-2010”, EKIS Journal, Vol. 8, No. 2, August 2012.

Alhasymi, M. (2012). Analisis Kausalitas dan Kointegrasi Antara Foreign Direct Investment (FDI) dengan Pertumbuhan Gross Domestic Product (GDP) di Australia (Metode Cointegrasi test dan Granger (ausality test).

Faoziyyah, A. A., \& Laila, N. (2020). Faktor Internal Dan Faktor Makroekonomi Yang Mempengaruhi Profitabilitas Asuransi Syariah Di Indonesia Periode 2016-2018. Jurnal Ekonomi Syariah Teori Dan Terapan, 7(6), 1146. https://doi.org/10.20473/VOL7ISS20206PP1146-1163 